\title{
Researches on Optimal Tax Rate and Its Effect of Copper Mine Resource Tax in China
}

\author{
Wenting Zhao, Minyi Guan \\ Department of Accounting, Guangzhou College of Commerce, Guangzhou, China \\ Email address: \\ 602821406@qq.com (Wenting Zhao),740749219@qq.com (Minyi Guan)
}

\section{To cite this article:}

Wenting Zhao, Minyi Guan. Researches on Optimal Tax Rate and Its Effect of Copper Mine Resource Tax in China. American Journal of Environmental and Resource Economics. Vol. 4, No. 2, 2019, pp. 54-64. doi: 10.11648/j.ajere.20190402.12

Received: March 31, 2019; Accepted: April 28, 2019; Published: June 11, 2019

\begin{abstract}
As an important natural resource, mineral resources are indispensable necessities for human's social existence and economic development. As China's industrialization process continues to gradually increase, conflicts about resource constraint and ecological pressure resulting from economic and social development are increasingly evident. Key problems of how to guarantee the security of national mineral resources supply, ease the contradiction of resource constraint, and reduce ecological pressure are significant current challenges in China. The Chinese government has successively implemented new types of resource taxes including "ad valorem duty" and "free fee and regulate tax" reform for oil, natural gas, and coal resources in an attempt to adjust differential income needs and protect resources. Given these efforts, there have also been strategies to reform policies for the use and taxation of non-ferrous metal resources. In 2016, the Chinese Ministry of Finance and the State Council jointly issued a government document to comprehensively promote the reform of resource tax policy. This document also set the standards of tax rate for seven metal minerals. Copper is one of the regulated minerals, and the tax rate range of copper mine was set as $2 \%$ to $8 \%$, dependent on the conditions of different provinces. We constructed a resource computable general equilibrium (CGE) model to investigate the optimal tax rate of copper resource under ad valorem duty in China. The results showed that the best tax rate is $4 \%$. Based on this optimal rate, a dynamic CGE model was built to analyze and dynamically forecast the macroeconomic impact of different tax rates, providing insight into the best strategy to enable cost control for enterprises and efficient and effective policymaking by the government. Because comprehensive resource tax reform remains in the exploratory stage, the results of this study will provide a reference for the future optimization of the copper mine resource tax rate.
\end{abstract}

Keywords: Ad Valorem Duty, CGE Model, Copper Resource Tax, Macroeconomic Impact, Optimal Tax Rate

\section{Introduction}

As an important component of the ecosystem, mineral resources play a crucial role in multiple areas of everyday life. At the same time, holdings of mineral resources serve as a basic indicator to measure comprehensive national power, indicate the potential of national economic development, and may shape national strategic security [1]. Generally speaking, mineral resources can be classified as energy minerals, metal minerals, nonmetal minerals, and water resources according to their use criteria. Compared with other natural resources, mineral resources are limited, nonrenewable, scarce, dynamic, and with uneven distribution areas. China has a considerable variety of mineral resources, at least 171 varieties, 158 of which have proved reserves. China's resources are also abundant. According to early statistics from the Ministry of
Land and Resources, China's total amount of mineral resources account for about $12 \%$ of the world's resources, second only to the United States and ahead of the Soviet Union. However, China's per capita holding of resources is only $58 \%$ of the world average, ranking 53rd in the world [2]. However, since the 1990s, there has been increased demand for mineral resources caused by the acceleration of China's industrialization process and the rapid consumption of resources due to traditional pattern of economic growth. Although national mining, dressing, smelting, production, and sales continue to grow, the pressure for self-sufficiency in mineral production is increasing, as reliance on overseas resources continues to increase. At the same time, the extensive utilization of resources has also caused enormous pressure on the ecological environment [3].

Resource taxes focus on energy, mineral, and other natural 
resources as the object of tax collection, as a way to adjust the income gap between different mines and to reflect the real value of the state-owned resources [4]. The collection mechanism of Chinese resource tax reform has undergone a transition from price-based to volume-based, and is moving towards full implementation of the "ad valorem duty" and "free fee and regulate tax." The excess progressive tax was the first form of resource tax in China, implemented in 1986. Subsequently, the government promoted the "Mineral resources law of the People's Republic of China," and simultaneously enacted a volume-based tax mechanism for seven resources, with specific tax amounts for different provinces. However, with the rapid economic growth, this volume-based tax mechanism has been insufficient to meet the new growing demand, due to its small effective range, low tax amounts, and a lack of correlation with the actual values of the taxed resources [5]. To deal with these inadequacies, the government has made multiple revisions to the initial policies of resource tax collection. An overview of the reform process of Chinese resource tax is shown in Table 1.

Table 1. Overview of resources tax reforms in China.

\begin{tabular}{|c|c|c|}
\hline Time & Period characteristics & Resource tax reform measures \\
\hline 1984-1986 & $\begin{array}{l}\text { The start-up stage of } \\
\text { resource tax in China. }\end{array}$ & $\begin{array}{l}\text { The promulgation of "The Resource Tax Regulations (Draft) of People's Republic of China" (referred to as } \\
\text { the Resource Tax Regulations (Draft)); } \\
\text { resource tax items: coal, oil, and natural gas; } \\
\text { excess progressive tax (i.e. ad valorem duty) }\end{array}$ \\
\hline 1986-1992 & $\begin{array}{l}\text { The start-up stage of } \\
\text { volume-based reform of } \\
\text { resource tax. }\end{array}$ & $\begin{array}{l}\text { January } 1^{\text {st }} 1986 \text {, the China Ministry of Finance issued "The Notification of Resource Tax Reform for Coal } \\
\text { Mines," in which the coal resource tax was levied based its volume quota. } \\
\text { In March 1986, "The Mineral Resources Law of the People's Republic of China" was promulgated: mineral } \\
\text { resource tax and resource compensation fees should be paid in accordance with the relevant regulations of } \\
\text { the state. }\end{array}$ \\
\hline $1992-2004$ & $\begin{array}{l}\text { The development stage of } \\
\text { volume-based reform of } \\
\text { resource tax. }\end{array}$ & $\begin{array}{l}\text { In the background of the system of tax distribution reform in China, the "Provisional Regulations on } \\
\text { Resource Tax" was enacted; } \\
\text { resource tax items: crude oil, natural gas, coal, other non-metal ores, ferrous metal ores, non-ferrous metal } \\
\text { ores, and crude salt; } \\
\text { different resource tax rate: } \\
\text { crude oil: } 8-30 \text { yuan per ton; } \\
\text { natural gas: } 2-15 \text { yuan / thousand cubic meters; } \\
\text { coal resource tax: } 0.3-5 \text { yuan / ton. As the mining conditions of coal resources vary, the tax rate is not same in } \\
\text { different provinces and cities. Additionally, the quota standards for resources tax in different provinces and } \\
\text { municipalities are also different. }\end{array}$ \\
\hline 2004-2010 & $\begin{array}{l}\text { The optimization stage of } \\
\text { volume-based reform of } \\
\text { resource tax. }\end{array}$ & $\begin{array}{l}\text { The government has adjusted the policy of coal resource tax frequently, especially in the provinces of } \\
\text { Shanxi, Qinghai, Henan, Anhui, Hubei, and Guangdong, covering nearly } 30 \text { provinces and cities nationwide. } \\
\text { The general adjustment procedure is to raise the threshold of tax standard for the coal mine; } \\
\text { In } 2007 \text {, The China Ministry of Finance issued "The notice about the adjustment of coal resource tax rate," } \\
\text { which specifies: } \\
\text { coal resources tax } 8 \text { yuan / ton; } \\
\text { crude oil: } 16-30 \text { yuan per ton; a special income fund for petroleum was first levied in } 2006 \text {; } \\
\text { natural gas resource tax: } 7-15 \text { yuan / thousand cubic meters. }\end{array}$ \\
\hline $2010-2014$ & $\begin{array}{l}\text { The start-up stage of "ad } \\
\text { valorem duty" reform of } \\
\text { resource tax }\end{array}$ & $\begin{array}{l}\text { Using Xinjiang as a pilot, the policies of "ad valorem duty" and "free fee and regulate tax" were implemented } \\
\text { for oil and natural gas starting November } 1^{\text {st }} 2011 \text {, both target } 5 \% \text { to } 10 \% \text { of sales. }\end{array}$ \\
\hline 2014-2016 & $\begin{array}{l}\text { The development of "ad } \\
\text { valorem duty" reform of } \\
\text { resource tax }\end{array}$ & $\begin{array}{l}\text { The policies of "ad valorem duty" and "free fee and regulate tax" were implemented as the coal resource tax } \\
\text { starting December } 1^{\text {st }} 2014 \text {; } \\
\text { Different provinces have different tax rates for coal mine; the tax rates for Henan, Hebei, Liaoning, Hunan, } \\
\text { Guangxi, Shandong, and Guizhou are } 2 \%, 2 \%, 2 \%, 2.5 \%, 2.5 \%, 4 \%, 5 \% \text {, respectively. The tax rates of } \\
\text { coal-producing provinces, such as Shanxi and Inner Mongolia, respectively, are } 8 \% \text { and } 9 \% \text {. } \\
\text { The government adjusted the iron ore resource tax on May } 1^{\text {st }} 2015 \text {, decreasing the tax by } 60 \% \text { in preparation } \\
\text { for the next ad valorem duty reform for metal resource taxation. }\end{array}$ \\
\hline 2016-now & $\begin{array}{l}\text { The comprehensive } \\
\text { promotion stage of "ad } \\
\text { valorem duty" reform of } \\
\text { resource tax }\end{array}$ & $\begin{array}{l}\text { July } 1^{\text {st }} 2016 \text {, the Chinese Ministry of Finance and the State Council jointly issued "the notice to } \\
\text { comprehensively promote the reform of resource tax," which promotes the reform of "ad valorem duty" and } \\
\text { "free fee and regulate tax" for metallic minerals, non-metallic minerals, and sea salt. The tax rates of } 7 \text { metal } \\
\text { mines were set. }\end{array}$ \\
\hline
\end{tabular}

In the government document published in 2016, the resource tax rate of the copper mine was stipulated. In the field of mineral resources, copper is of great significance due to its wide application and important role in national economic development. Of the 124 basic industries in China, 113 use copper products, showing copper's fundamental strategic position, second only to oil [6]. Currently, China is the largest copper consumer and largest copper product exporter in the world. However, China's mines have more lean ore and lack scale ore, thus requiring high production costs to extract the copper. The state of Chinese copper mining and usage in our country is shown in Figure 1 (source: "China nonferrous metals industry yearbook (2009-2016)" and the Wind Data Base). 


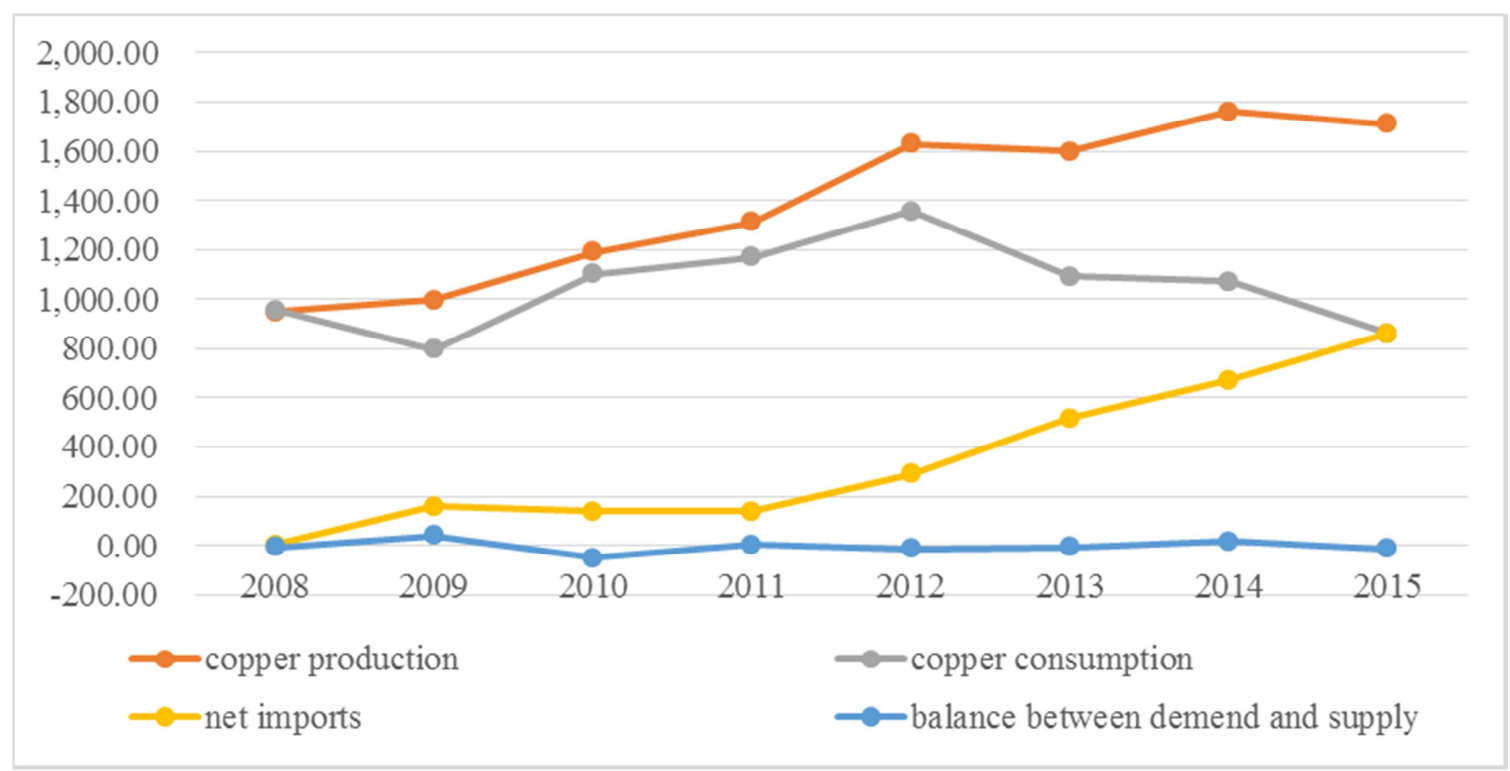

(unit: ten thousand ton).

Figure 1. Chinese copper resources in 2008-2015.

Figure 1 shows the risk of insufficiency of Chinese copper production to meet demand. The main reason for this, besides the limitations of the natural resources, is related to the low use efficiency of domestic mining. Therefore, with the continued increased demand, the copper tax policy and its role in promoting efficient copper production should be evaluated. Before 2016, China's copper resource tax policy included both taxes and fees. The tax amounts steadily increased (the first-class mining levy was changed from 1.6 yuan/ton to 7 yuan/ton in 2008) [7]. Since July 2016, China's copper resources tax has been levied in an ad valorem manner, and other relevant fees and resource compensation funds have been abolished. Overall, the tax rate range for copper mines varies from $2 \%$ to $8 \%$ according to the condition of different provinces.

Since 2012, affected by the heavy burden of tax and fee, a downward trend is obvious for the copper consumption market. After the reform of copper resource tax, the tax amount can be adjusted spontaneously with the market price of copper. Although the implementation of the reform was less than a year ago, the reform has already shown great success. For example, for the Daxing copper mine, in Jiangxi province, the sum of tax payable decreased by 56110 thousand yuan, $42.9 \%$ of the total tax burden. The growth of operation performance was obvious in the four months after the copper resource tax reform. However, this reform was also accompanied by many problems and difficulties, especially the complicated determination of the specific tax rates. The range of copper resource tax rates is set on the national level, but the specific tax rate is determined in accordance with the actual condition of each province. Therefore, it is of great significance both theoretically and practically to study the approach of local governments to determine the appropriate tax rates.

Here, we determine the optimal copper resource tax rate and analyze its macroeconomic impact under the ad valorem duty. For comprehensive resource tax reform that is still in the exploratory stage, the results of this study will provide a reference for the further optimization and improvement of the resource tax rate of copper mine.

\section{Literature Review}

International research on resource tax has been relatively systematic and comprehensive. The ideas of "resource depletion" and "the theory of time tilt" first introduced the significance of resource tax collection [8] and were later modified to include variables of externalities [9], market interest rates [10], base period price [11], and government credibility [12] to improve the theoretical foundation of resource tax calculation. Different models and methods have been used for resource tax rate design and understanding the non-renewable natural resources depletion value is required for optimal tax calculation. Barker designed Britain's "energy - environment - economy" model to determine a reasonable range of carbon tax [13]. Boadway and Keen analyzed the tax rate for oil and minerals from a theoretical perspective using the net rent calculation [14], which took environmental issues into consideration. The effect of resource tax collections focused on the impact on specific industries. Kunce explored the consequences of tax changes on the oil industry in the United States [15]. Sderholm analyzed mineral products consumption and showed that the mineral raw material resource tax has high environmental utilization [16].

In contrast, domestic research on resource tax has focused on tax basis, resource tax reform, and the Chinese resource tax system. Among Chinese scholars, there is near consensus that ad valorem duty is a better approach than volume-based resource taxing. For instance, Duan proposed that resource tax collection should be based on the amount of profit earned, 
incorporating information about mining conditions and recovery factors [17], and Shang suggested Chinese resource taxes should be appropriately increased [18]. A free fee and regulate tax approach is similarly favored by Chinese academics. Some scholars proposed that resource tax and mineral resources compensation fees are redundant with each other and suggested that the use of only resource taxes can reduce management costs and enhance industry competitiveness. These taxes may also increase transparency to avoid disputes between different departments and reduce problems with rent-seeking corruption [19]. The "ad valorem duty" and "free fee and regulate tax" reform of the resource tax enacted in 2016 conformed to the mainstream ideas of academic circles. With continued resource tax reform, there are more studies to quantitatively measure the effects and benefits of reform. Zhang applied a regional perspective to China's resource tax reform to quantitatively calculate its degree of influence and qualitatively analyze its mechanism of influence by adopting an energy computable general equilibrium model and a Social Accounting Matrix (SAM) price model. The results show that the main significance of reform lies in bolstering local government finances rather than improvements in energy conservation or carbon reduction [20]. $\mathrm{Xu}$ studied the influences on economy, resources, and the environment with different coal resource tax policy scenarios from a regional perspective. The stimulated results showed that coal resource tax reform had a negative influence on Gross Domestic Product (GDP). However, coal resource tax reform can increase regional revenues (especially in resource-rich regions), explaining the observed increase of GDP in some regions, suggesting a potential strategy to narrow regional economic gaps [21]. In the existing tax system in China, most scholars agree that the amount of unit resource tax collection is insufficient to reflect the differential profits between inferior and superior mine resources. In addition, the collection scope is also too narrow, contrary to the principle of equitable burden [22]. Xu also studied the Chinese region effects of reform and came to a conclusion that the reform of resource taxes can adjust the regional difference [23].

Previous domestic and international studies have relied on mostly qualitative analysis, particularly for the design of resource tax rates. Lin used the modified EI Serafy user cost method to estimate the cost of coal resource depletion, and proposed that the coal resource tax rate should be $5 \% \sim 12 \%$ under ad valorem duty [24]. Lin also studied the resource tax rate of oil and nature gas by quantitative analysis of a computable equilibrium model (CGE model) and found that a resource tax below $20 \%$ on oil and gas will not have a large negative impact on the macro-economy [25]. For the metal mine, Zhong used the adjusted El Serafy user cost approach to estimate the depletion cost and determined a theoretical tax range for metal minerals of 5-20\%. A dynamic CGE model was also applied to investigate the impacts of metal resource tax reform on China's economy [26].

Quantitative research on natural resource taxation has focused on coal, oil, natural gas, and metal minerals. However, there has been no study of a single metal mineral resource. Here, we use quantitative-based determination of the appropriate resource tax of a copper mine to meet the needs of local government, which has not been studied previously.

We established a CGE model to perform our analysis and then calculated the optimal tax rate. Based on our results, we then built a dynamic CGE model to analyze and dynamically forecast the macroeconomic impact of different taxes and assess reform utility.

\section{Materials and Methods}

CGE models have been widely used in many fields including studies of resources, environment, and public finance. Using a regional CGE model, Bollen studied the correlation between the cost of government climate policy and greenhouse gas emissions [27]. Philip examined the feasibility of the replacement of gasoline with biodiesel in France with a dynamic CGE model and concluded that $10 \%$ of the resource rate was insufficient to achieve the government's intended target [28]. Overall, previous studies have shown that CGE provides a comprehensive approach to study resource tax rate design.

\subsection{The CGE Model}

In addition to basic parameters, a basic CGE model also includes the detailed data of various industry departments. Based on known data, we established static (resource) and dynamic CGE models to design the optimal copper resource tax rate and analyze its macroeconomic impact in China. CGE was selected for the following reasons: 1) The model is a widely accepted tool to study resource taxes. 2) In China, there are existing policies for coal, oil, natural gas, and even comprehensive policies for resources [29] to allow analysis of tax design and impact using CGE model. 3) Applying the dynamic CGE model to measure China's economic impact allows consideration of the specific policies of the country, an effective improvement to the static CGE model. For convenience, we do not consider foreign departments in the specific application of the static CGE, but do include production, consumption, and equilibrium to ascertain the optimal tax rate. On this basis, a dynamic CGE model was built using a dynamic recursive mechanism to study macroeconomic influence [30], as shown in Figure 2. 


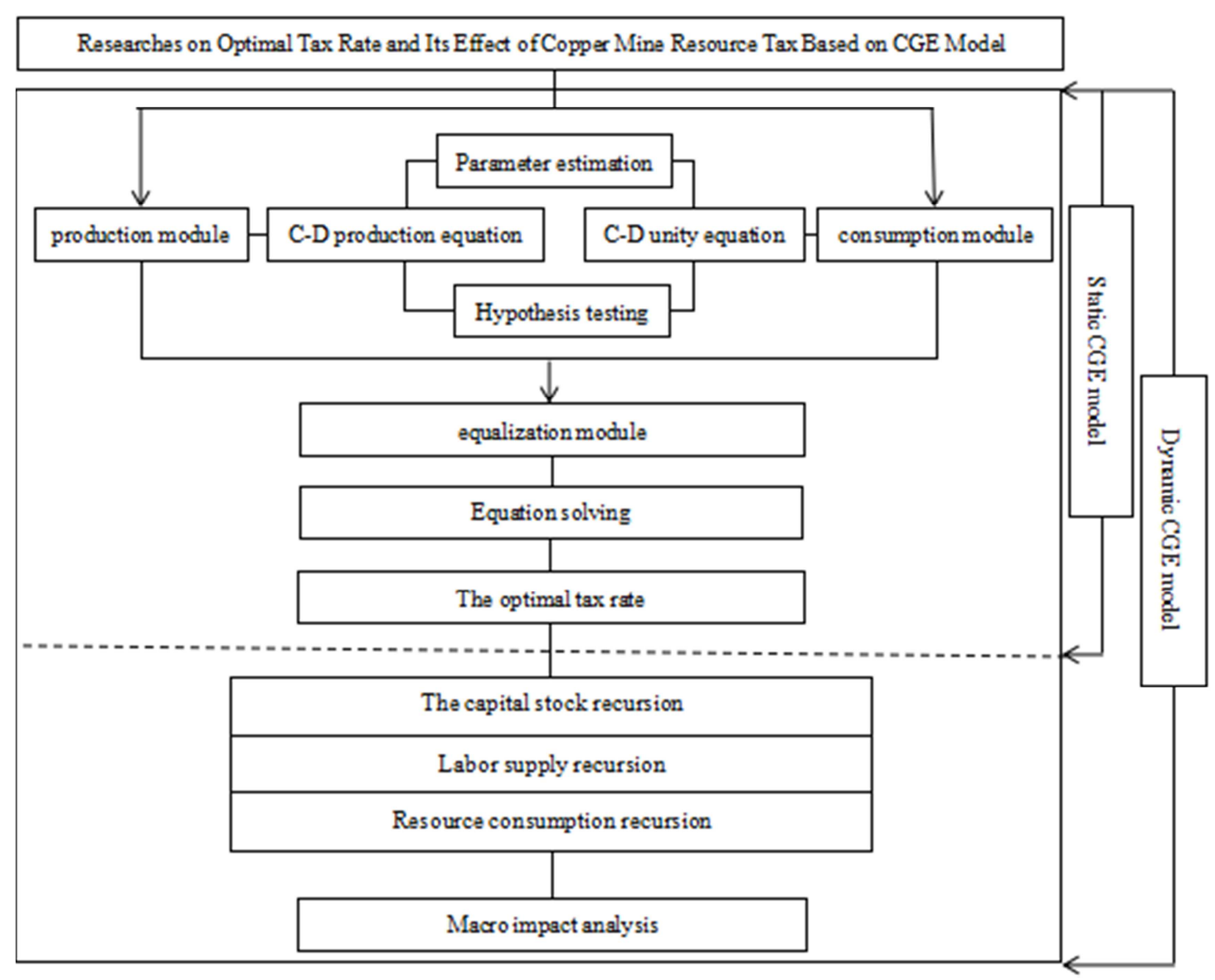

Figure 2. The basic framework of copper tax rate in the CGE model.

\subsection{The Building of Model Function}

\subsubsection{Static CGE Model for Copper Resource Tax Rate}

$\mathrm{C}-\mathrm{D}$ production equation:

$$
Q=F(K, L, R)=A K^{\alpha} R^{\beta} L^{\gamma} \quad(\alpha+\beta+\gamma=1)
$$

Where, Q, K, L, and $\mathrm{R}$ respectively refer to the concept output, capital, labor, and resource; A represents the transfer parameters showing the technological progress of productivity; when the output is 1 , then $\alpha, \beta$, and $\gamma$ are share parameters, based on $\mathrm{K}, \mathrm{L}, \mathrm{R}$, all of which satisfy the same returns to scale.

Both sides of the equation were divided by L, to get formula (2). The input of elements such as capital, labor, and resources are converted into per capita elements for output q.

$$
q=f(k, r)=A K^{\alpha} R^{\beta} \quad(\alpha+\beta<1)
$$

Based on this, at a minimum cost for producers, formula (3) will be obtained, allowing the calculation of the corresponding coefficients like the per capita capital amount $\mathrm{k}$ and the per capita resource consumption $r$. Where, $T_{k}$ is the capital rate, $T_{r}$ refers to resource tax rates, and $\mathrm{z}, \boldsymbol{\theta}$, and $\mathrm{w}$ are the prices of capital, resources, and labor, respectively. $T_{1}$ represents labor rates.

$$
\operatorname{Min} C(k, r)=\left(1+T_{K}\right) \times z \times k+\left(1+T_{r}\right) \times \theta \times r+\left(1+T_{L}\right) \times w
$$

Formula (4) is obtained from formula (2) after the equation transformation of linear estimation.

$$
\begin{aligned}
\ln (q) & =\ln (A)+\alpha \ln (k)+\beta \ln (r) \\
k & =\left|\frac{q}{A}\right|^{\frac{1}{\alpha+\beta}}\left|\frac{\alpha\left(1+T_{r}\right) \theta}{\beta\left(1+T_{k}\right) z}\right|^{\frac{\beta}{\alpha+\beta}} \\
r & =\left|\frac{q}{A}\right|^{\frac{1}{\alpha+\beta}}\left|\frac{\beta\left(1+T_{k}\right) z}{\alpha\left(1+T_{r}\right) \theta}\right|^{\frac{\alpha}{\alpha+\beta}}
\end{aligned}
$$

C-D unity equation:

$$
\begin{gathered}
U=C_{p}^{m} \times C_{g}^{n} \quad(m+n=1) \\
C_{p}=\left(1-T_{L}\right) \times w-T_{r} \times \theta_{r} \\
C g=\mu\left(T_{L} \times w+T_{k} \times z \times k+T_{r} \times \theta_{r}\right)
\end{gathered}
$$

Where, $\mathrm{C}_{\mathrm{p}}$ indicates private consumption, $\mathrm{C}_{\mathrm{g}}$ is government consumption, $\mathrm{m}$ refers to residents' consumption elasticity 
coefficient, and $\mathrm{n}$ is the public consumption elasticity coefficient.

(3) Equalization module equation

Equilibrium module represents the supply and demand balance, shown as formula (10).

$$
q=C_{p}+C_{g}
$$

In addition, for producers, there is an equilibrium output and equilibrium capital price, where the marginal cost equals marginal revenue, shown as formulas (11) and (12).

$$
\begin{gathered}
q^{*}=\frac{\left(1-T_{L}\right) w+\mu T_{L} w}{1-\mu \alpha T_{k} /\left(1+T_{k}\right)+(1-\mu) \beta T_{r} /\left(1+T_{r}\right)} \\
z^{*}=\left|\frac{\alpha q^{*}}{1+T_{k}}\right|^{\frac{\alpha+\beta}{\alpha}}\left|\frac{A}{q^{*}}\right|^{\frac{1}{\alpha}}\left|\frac{\beta\left(1+T_{k}\right)}{\alpha\left(1+T_{r}\right) \theta}\right|^{\frac{\beta}{\alpha}}
\end{gathered}
$$

\subsubsection{Dynamic CGE Model for Macroeconomic Impact}

To reduce the necessary amount of calculation, we use the above resource model results and included a dynamic mechanism to build the dynamic CGE model, as follows:

$$
\begin{aligned}
& K_{n+1}=(1-\delta) K_{n}+I_{n} \\
& L_{n+1}=(I+n g) \times L_{n} \times C_{n+1} \\
& C C_{1}=p i n V_{1}+(i r+D E P R)
\end{aligned}
$$

$$
I T_{1}=\operatorname{pin} V_{1} \sum I_{i}
$$

$$
Q E(t)=\left[\left(\sum E R E(t-1)-\sum Q R(t)\right) \sum_{0}^{t} w\right] P
$$

In formula (13), the summation of the current capital stock deducts depreciation and the current investment becomes the capital stock in the next phase. Formula (14) shows the social labor supply in the next period, calculated as the current labor supply multiplied by population growth. Formula (15) shows that the capital use-cost is equal to the product of the current investment price index and the summation of the current interest rate and discount rate. In formula (16), all of the terminal investments are added to form the national total. For the resource recursive equation (17), $\mathrm{QE}(\mathrm{t})$ is the total value of resources, ERE ( $t$ - 1) is the resource recovery in the last installment, $Q R(t)$ is the current capital stock, and $\mathrm{w}$ represents the degree of resource exploitation as a time distribution function. $\mathrm{P}$ is the resource price.

\subsection{The Basic Data and Correlation Parameters of the CGE Model}

In this study, the corresponding variables were obtained from the Chinese statistical yearbooks and the Wind database. Through the collation and accounting of the statistical data for 1996-2016 years, we were able to obtain the specific values of per capita output (q), per capita investment (k), and per capita resource consumption (r) for the past 20 years. Among them, the

\begin{tabular}{|c|c|c|c|c|c|c|}
\hline Year & $q$ (yuan) & $L n q$ & k(yuan) & Lnk & $r(\mathrm{~kg})^{1)}$ & $L n r$ \\
\hline 1996 & $5,898.00$ & 8.68 & 1872.19 & 7.53 & 0.98 & -0.02 \\
\hline 1997 & $6,481.00$ & 8.78 & 2017.46 & 7.61 & 1.03 & 0.03 \\
\hline 1998 & $6,860.00$ & 8.83 & 2276.85 & 7.73 & 1.17 & 0.16 \\
\hline 1999 & $7,229.00$ & 8.89 & 2373.45 & 7.77 & 1.31 & 0.27 \\
\hline 2000 & $7,942.00$ & 8.98 & 2597.20 & 7.86 & 1.42 & 0.35 \\
\hline 2001 & $8,717.00$ & 9.07 & 2915.80 & 7.98 & 1.57 & 0.45 \\
\hline 2002 & $9,506.00$ & 9.16 & 3386.44 & 8.13 & 1.85 & 0.62 \\
\hline 2003 & $10,666.00$ & 9.27 & 4299.92 & 8.37 & 2.02 & 0.70 \\
\hline 2004 & $12,487.00$ & 9.43 & 5421.84 & 8.60 & 2.25 & 0.81 \\
\hline 2005 & $14,368.00$ & 9.57 & 6789.26 & 8.82 & 2.51 & 0.92 \\
\hline 2006 & $16,738.00$ & 9.73 & 8368.19 & 9.03 & 2.89 & 1.06 \\
\hline 2007 & $20,505.00$ & 9.93 & 10393.17 & 9.25 & 3.45 & 1.24 \\
\hline 2008 & $24,121.00$ & 10.09 & 13013.99 & 9.47 & 3.84 & 1.35 \\
\hline 2009 & $26,222.00$ & 10.17 & 16830.18 & 9.73 & 4.57 & 1.52 \\
\hline 2010 & $30,876.00$ & 10.34 & 18769.62 & 9.84 & 5.07 & 1.62 \\
\hline 2011 & $36,403.00$ & 10.50 & 23118.35 & 10.05 & 5.44 & 1.69 \\
\hline 2012 & $40,007.00$ & 10.60 & 27672.35 & 10.23 & 5.67 & 1.74 \\
\hline 2013 & $43,852.00$ & 10.69 & 32798.38 & 10.40 & 6.03 & 1.80 \\
\hline 2014 & $47,203.00$ & 10.76 & 37433.34 & 10.53 & 6.38 & 1.85 \\
\hline 2015 & $49,992.00$ & 10.82 & 40884.01 & 10.62 & 6.66 & 1.90 \\
\hline 2016 & $53,980.00$ & 10.90 & 43860.68 & 10.69 & 7.21 & 1.98 \\
\hline
\end{tabular}
consumption of resource was determined as the summation of copperware such as copper processing materials and wire rods [31] based on data from the "China nonferrous metals industry yearbook," divided by the annual Chinese population to get the per capita resource consumption of copper. This data is shown in Table 2.

Table 2. Data summation of production module.

Kg: kilogram.

Data source: China Statistical Yearbook(1996-2016). 
In the consumption module, we used data from 1996 to 2016 to estimate government consumption and the consumption elasticity coefficient for residents (using data from the China statistical yearbook and the Wind data base). According to statistics, the overall average ratio was 2.85 , and the residents' consumption elasticity coefficient was 0.74 when that of the government was 0.26 and $\mu$ was 0.83 . In addition, based on work from Zhihui Ye [32] on the determination of fuel tax rates, we set the labor rate as $6.62 \%$ and the capital tax rate as $45.65 \%$. The labor price was calculated based on the average wage of employed workers from 1996 to 2016, 29782.3. The resource price was calculated using copper revenues and output elements as 228.48 yuan/ton.

The analysis of the industrial data was performed using the dynamic CGE model. Based on the literature, we used the newest Chinese energy environment Social Accounting Matrix (SAM), as shown in Table 3, as the basic data in our CGE model, and the data are subjected to the cross-entropy method to solve the conflict among different sources based on the Shannon value.

Table 3. The social accounting matrix (SAM) (unit: 10^8 yuan).

\begin{tabular}{|c|c|c|c|c|c|c|c|c|c|}
\hline & Production & Recovery & Labor & Capital & Resource & People & Department & Government & saving \\
\hline Production & 818,859 & & 28,244 & 117,478 & 552,815 & & & & \\
\hline Recovery & & 90 & & & & & & & \\
\hline Labor & 28,244 & & & & & & & 3,185 & \\
\hline Capital & 117,478 & & & & & & & 9675 & \\
\hline Resource & 552,815 & & & & & & & 261 & \\
\hline People & & & & & & & & & 175,700 \\
\hline Department & & & & & & & 117,478 & & 122,751 \\
\hline saving & & & & & & 175,700 & 122,751 & 1522 & \\
\hline
\end{tabular}

According to the parameters in Table 3, we examined the balance problem caused by different sources and quality of statistical material in SAM. Additional data used were from the statistical yearbook of China (1997-2016), the Wind data base, the China financial yearbook, the China nonferrous metals industry yearbook, and the China energy statistical yearbook.

\section{Results and Discussion}

\subsection{The Optimal Rate of Copper Resource Tax From Static CGE}

The linear parameter estimation results for the production module are presented in Tables 4 and 5 . The $\mathrm{R}^{2}$ of the model was 0.9985 , and 0.9893 after adjustment. At 5\% significance level, every coefficient passes the test. Therefore, the production function formula (18) and the utility function (19) were used in the production module.

$$
\begin{array}{r}
\mathrm{q}=19.36 k^{0.59} r^{0.16} \\
\mathrm{U}=C_{p}^{0.74} C_{g}^{0.26}
\end{array}
$$

Table 4. Linear parameter estimation in production module.

\begin{tabular}{lllll}
\hline Model & $\mathbf{R}$ & $\mathbf{R}^{\mathbf{2}}$ & Adjusted $\mathbf{R}^{\mathbf{2}}$ & Estimated error \\
\hline 1 & $0.993 \mathrm{a}$ & 0.9985 & 0.9983 & 0.04197 \\
\hline
\end{tabular}

\begin{tabular}{|c|c|c|c|c|c|}
\hline \multirow{2}{*}{ Model } & \multicolumn{2}{|c|}{ The unstandardized coefficient } & \multirow{2}{*}{$\begin{array}{l}\text { Standardized } \\
\text { coefficient }\end{array}$} & \multirow{2}{*}{$\mathbf{t}$} & \multirow{2}{*}{$\mathbf{P}>|\mathbf{t}|$} \\
\hline & B & Standard error & & & \\
\hline (constant) & 2.963 & 0.377 & 19.36 & 11.23 & 0.000 \\
\hline Lnr & 0.158 & 0.084 & 0.16 & 1.87 & 0.007 \\
\hline Lnk & 0.593 & 0.051 & 0.59 & 11.58 & 0.000 \\
\hline
\end{tabular}

Table 5. The simulative results of model parameters.

Therefore, by incorporating statistics into the resource CGE model, we can obtain the equilibrium results of relevant variables, as shown in table 6 . Figure 3 shows the maximum utility for different copper resource taxes.

\begin{tabular}{|c|c|c|c|c|c|c|c|}
\hline $\mathbf{T r}$ & $q^{*}$ & $\mathbf{Z}^{*}$ & $\mathbf{k}^{*}$ & $\mathbf{r}^{*}$ & Cp & $\mathrm{Cg}$ & $\mathbf{U}$ \\
\hline $1 \%$ & 34775.16 & 1.49 & 13835.51 & 35.42 & 27729.78 & 9513.43 & 20996.55 \\
\hline $2 \%$ & 34764.32 & 1.48 & 13865.78 & 35.06 & 27650.48 & 9593.85 & 20998.01 \\
\hline $3 \%$ & 34753.70 & 1.48 & 13895.88 & 34.71 & 27572.78 & 9672.65 & 20998.95 \\
\hline $4 \%$ & 34743.29 & 1.48 & 13925.82 & 34.37 & 27496.63 & 9749.88 & 20999.39 \\
\hline $5 \%$ & 34733.08 & 1.47 & 13955.59 & 34.03 & 27421.98 & 9825.59 & 20999.37 \\
\hline $6 \%$ & 34723.07 & 1.47 & 13985.19 & 33.70 & 27348.78 & 9899.81 & 20998.93 \\
\hline $7 \%$ & 34713.26 & 1.46 & 14014.64 & 33.37 & 27276.99 & 9972.61 & 20998.08 \\
\hline $8 \%$ & 34703.63 & 1.46 & 14043.93 & 33.05 & 27206.58 & 10044.00 & 20996.87 \\
\hline $9 \%$ & 34694.18 & 1.46 & 14073.05 & 32.74 & 27137.50 & 10114.04 & 20995.30 \\
\hline $10 \%$ & 34684.91 & 1.45 & 14102.03 & 32.43 & 27069.72 & 10182.77 & 20993.42 \\
\hline
\end{tabular}

Table 6. The equilibrium data of copper resources tax for different rates (unit: yuan). 


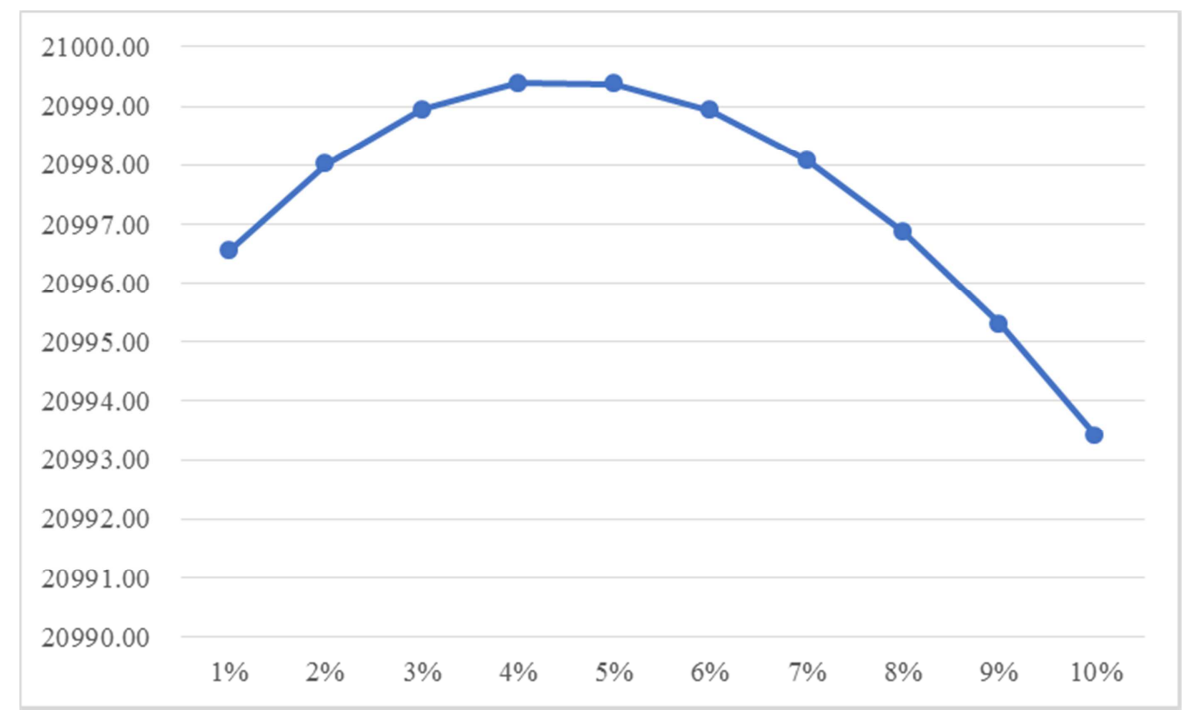

Figure 3. The maximum utility analysis for different copper tax resource rates (unit: yuan).

According to the above charts, when the tax rate is $4 \%$, consumer utility is maximum, indicating the optimal copper tax rate is $4 \%$. Considering the direct and representative needs of results analysis, we selected $4 \%$ as the middle value and used $1 \%$ and $10 \%$ as reference values to evaluate the impact of related elements, as shown in Figure 4 and 5.

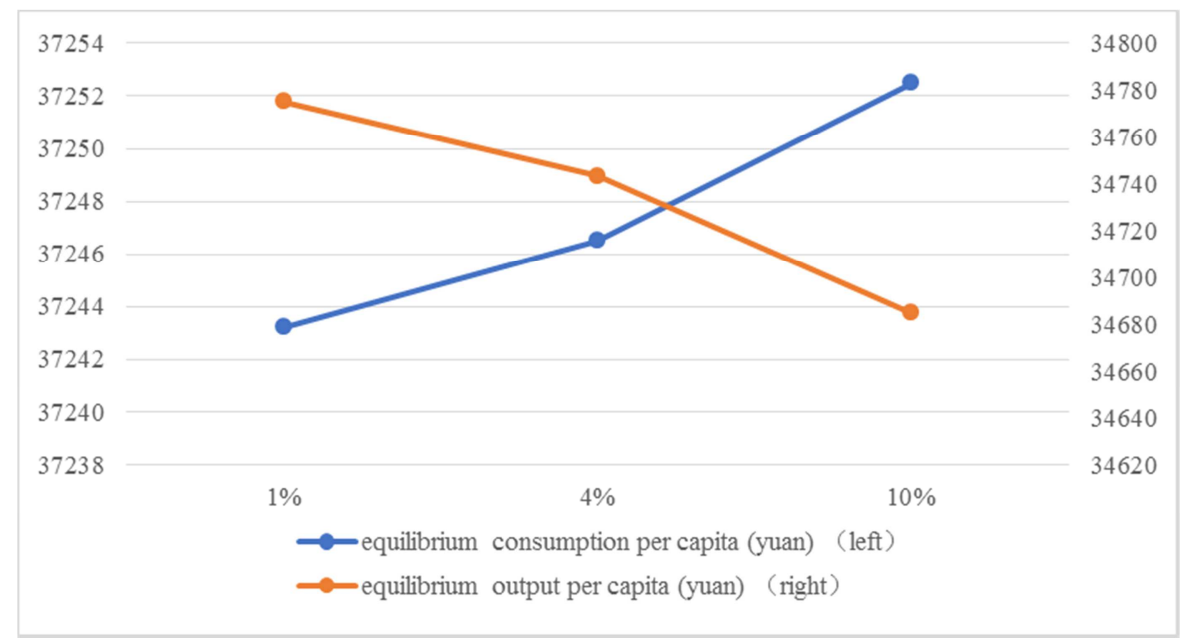

Figure 4. Equilibrium output and equilibrium capital dosage at different tax rates.

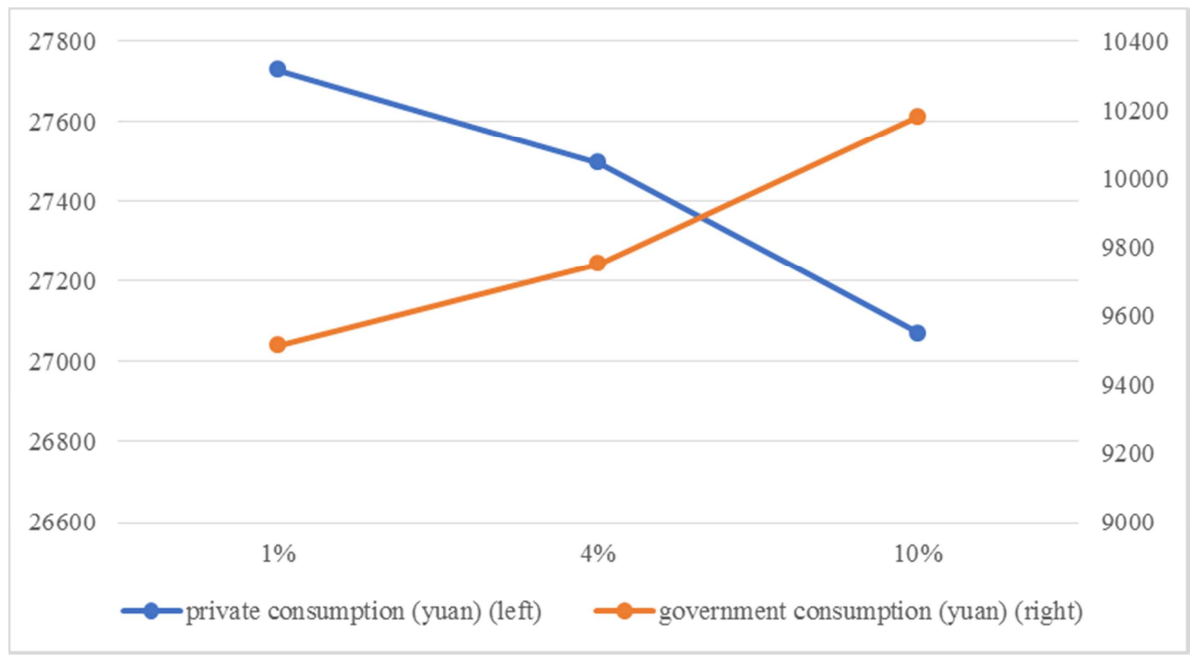

Figure 5. Total consumption of residents and government at different tax rates. 
According to the data aggregation of the comprehensive influence of copper resource for the three tax rates, Figures 4 and 5 show the trend of changing different elements. The balanced capital usage and resource tax rates are positively correlated and the trend of per capita output is opposite. As the copper mine resource tax rate increases, the government spending increases but private consumption decreases gradually.

\subsection{The Macroeconomic Influence Results from Dynamic CGE}

We tested copper resource tax rates of $1 \%, 4 \%$, and $10 \%$ in the dynamic CGE model to analyze the influence of tax rate on macroeconomic under ad valorem duty, using the dynamic model to model data corresponding to the years of 2016, 2018, and 2020. The simulation results are shown in Table 7.

Table 7. Macroeconomic effect under different copper resource tax rates.

\begin{tabular}{|c|c|c|c|c|c|}
\hline Copper resource tax rate(\%) & year & GDP (\%) & Total consumption (\%) & Total investment (\%) & Resource utilization (\%) \\
\hline \multirow{3}{*}{1} & 2016 & 0.132 & -0.171 & -0.032 & -0.374 \\
\hline & 2018 & 0.228 & -0.243 & -0.106 & -0.412 \\
\hline & 2020 & 0.294 & -0.206 & -0.084 & -0.403 \\
\hline \multirow{3}{*}{4} & 2016 & 0.067 & -0.031 & 0.002 & -0.051 \\
\hline & 2018 & 0.092 & -0.074 & 0.008 & -0.095 \\
\hline & 2020 & 0.104 & -0.042 & 0.014 & -0.063 \\
\hline \multirow{3}{*}{10} & 2016 & -0.079 & 0.094 & 0.142 & 0.011 \\
\hline & 2018 & -0.118 & 0.186 & 0.196 & 0.025 \\
\hline & 2020 & -0.103 & 0.162 & 0.231 & 0.039 \\
\hline
\end{tabular}

From the empirical results presented in Table 7, we can see that with the continuous increase of the copper resource tax rate, there will be a greater negative impact on the GDP. This is one of the reasons why the government has prudently implemented resource tax reform in recent years. In the meantime, the increase of tax rate will have a greater impact on the upstream and downstream enterprises of the copper industry, because the price of copper metal includes the tax cost. Moreover, as time goes by, the negative impact on GDP will become smaller due to the increase of the copper tax rate under the same conditions. This is due to the implementation of national security strategy and the adjustment of metal resources in the Chinese economic structure. As the copper resource tax rate increases, many sectors of the national economy will seek strategies to decrease dependence on metal resources.

In addition, total consumption and total investment are positively related to the copper resource tax rate. As an indirect tax, resource tax mainly affects the amount of savings and investment by changing the consumption tendency. For residents, improving the copper resource tax rate will increase the cost of resource use, which has a certain income effect and substitution effect. For the government, the resource tax will be converted into government savings, which will affect the amount of consumption and investment by the government. The total government savings will increase with the increase of the copper resource tax rate, and the corresponding total investment will change accordingly.

From the index of resource utilities in table 7, we can see that the copper resource utilization can be improved with the increase of the resource tax rate. Tax increases can promote the transformation of copper enterprises from "production guided" to "profit-oriented," and can stimulate enterprises to make adjustments and upgrade technology to reduce costs and form new industrial patterns between copper enterprises. Furthermore, from the consumer's point of view, if the copper tax rate is increased, copper prices will rise accordingly, which promotes the conservation of resources and improves the efficiency of resource utilization. In the long run, these types of taxes can stimulate the progress of technology and promote industrial structural optimization to drive economic growth.

\section{Conclusion}

With the "Notice on comprehensively promoting the reform of resource tax" (No. 53 document in 2016) issued by the Chinese Ministry of Finance and the State Council, the reform of "ad valorem duty" and "free fee and regulate tax" has been in a comprehensive promotion stage. In this document, the central government stipulates the scope of the tax rates for seven metal resources and 22 non-metal resources. The specific numerical formulation of the tax rate is set by the local government. Since this is the initial stage of the reform, the local government lacks experience in the formulation of the specific tax rate, and the tax rate given by local department is likely to rely on subjective judgment without basis in scientific theory. With the rapid development of Chinese economy and upgrading of the economic structure, the strategic positioning of copper resources becomes more and more important. Therefore, we studied the copper resource tax through the construction of the CGE model to investigate the optimal tax rate for copper resources and to determine the macroeconomic impact of different rates. This data can serve as a reference for the optimization and improvement of copper resource tax for policy-making by different provincial governments.

Using the resource CGE model, our results showed that theoretically, the optimal tax on copper resource is $4 \%$. On this basis, this paper studied the macroeconomic impact of different tax rates of $1 \%, 4 \%$, and $10 \%$ through the dynamic CGE model, and analyzed the ratio change of GDP, total consumption, investment, and resource utilization. Generally speaking, the increase of the copper resource tax rate has a negative impact on the GDP, and this negative impact on GDP 
will become smaller over time. Total consumption and total investment are positively related to the copper resource tax rate. Relatively high tax rates also play a positive role in the improvement of resource utilization.

Therefore, local governments should set reasonable copper tax rates according to their own needs and goals. The specific tax rate of copper resources tax is critical. If the tax rate is too low, it will not stimulate improvement of the utilization ratio of copper resource. However, a high tax rate will have a negative impact on Chinese economy, especially sectors that require copper metal. Therefore, reform of the copper resource tax should consider the effectiveness of the tax rate and the sensitivity of the macro-economy to the cost of copper resources into account. The simulation results of our paper provide theoretical support for the optimization and improvement of the copper resource tax rate for policy-making by both central and local governments. The simulation results show that the theoretically optimal tax rate of copper resource is $4 \%$ in China. Therefore, using $4 \%$ as a reference, local governments can perform further optimization of their policy-making of the copper tax rate by considering both local economic and environmental situations.

Based on the policy orientation of China's resource tax reform, this paper uses macro data and CGE model to test the optimal tax rate of China's copper resources tax. From the theoretical level, the research results will make up for the lack of academic research on the collection of single metal resources tax in China. From the practical level, it is concluded that the optimal tax rate of China's copper resources tax is $4 \%$ in this paper, which has guiding value for China's policy. However, affected by the extreme value of Yearbook data, the data in this paper is up to 2016. In addition, due to the limitation of the author's ability, the dynamic CGE model needs to be improved in data computational simulation, which will be the improvement direction of this paper. In the future, we will pay attention to the reform of China's tax system persistently, especially in the field of resource tax. On this basis, by optimizing the methodology and integrating the latest macro data, the research results will be more objective and accurate.

\section{Acknowledgements}

I would like to thank all the seminar participants at Guangzhou College of Commerce for their valuable comments and discussions. I also appreciate my teacher professor Zhou who provided much sound advice on this paper. All remaining errors are my own.

\section{References}

[1] Lusty, P. A. J., \& Gunn, A. G. 2015. Challenges to global mineral resource security and options for future supply. Geological Society, London, Special Publications, 393 (1), 265-276.

[2] Xu, Y., Li, J., \& Liu, L. 2016. Current Status and Future
Perspective of Recycling Copper by Hydrometallurgy from Waste Printed Circuit Boards. Procedia Environmental Sciences, 31, 162-170.

[3] Wen, Z., Zhang, C., Ji, X., \& Xue, Y. 2015. Urban mining's potential to relieve China's coming resource crisis. Journal of industrial ecology, 19 (6), 1091-1102.

[4] Xu X: 2011. Resource tax reform of tax rate choice: a resource CGE model analysis. Journal of Shanghai university of finance and economics., 13, 82-89.

[5] Zhou, Z., Chen, X., \& Xiao, X. 2013. On Evaluation Model of Circular Economy for Iron and Steel Enterprise Based on Support Vector Machines with Heuristic Algorithm for Tuning Hyperparameters. Applied Mathematics \& Information Science., 7, 2215-2223.

[6] Zhou, Z., Zhao, W., \& Wu, Z. 2015. Optimal Tax Rate and Its Effect on Copper Mine Resource Tax in China: A Computable General Equilibrium Model. World Researches on Science Development., 37, 443-449.

[7] Guo, C. 2004. Copper resources in China and the present situation of development. China metal bulletin, 6, 2-4

[8] Hotelling, H. 1931. The economics of exhaustible resources. Journal of political Economy, 39 (2), 137-175.

[9] Sandmo, A. 1975. Optimal taxation in the presence of externalities. The Swedish Journal of Economics, 86-98.

[10] Slade, M. E. 1980. The effects of higher energy prices and declining ore quality: Copper-aluminium substitution and recycling in the USA. Resources Policy, 6 (3), 223-239.

[11] Baranzini, A., Goldemberg, J., \& Speck, S. 2000. A future for carbon taxes. Ecological economics, 32 (3), 395-412.

[12] Chen, J. V., Jubilado, R. J. M., Capistrano, E. P. S., \& Yen, D. C. 2015. Factors affecting online tax filing-An application of the IS Success Model and trust theory. Computers in Human Behavior, 43, 251-262.

[13] Barker, T., Baylis, S., \& Madsen, P. 1993. A uk carbon/energy tax: the macroeconomics effects. Energy Policy, 21 (3), 296-308.

[14] Boadway, R., \& Keen, M. 2010. Theoretical perspectives on resource tax design. The Taxation of Petroleum and Minerals: Principles, Problems and Practice, 24, 13.

[15] Kunce, M., Gerking, S., Morgan, W., \& Maddux, R. 2003. State taxation, exploration, and production in the US oil industry. Journal of Regional Science, 43 (4), 749-770.

[16] Söderholm, P., \& Klaassen, G. 2007. Wind power in Europe: a simultaneous innovation-diffusion model. Environmental and resource economics, 36 (2), 163-190.

[17] Duan, Z., \& Liu, X. 2007. Coal full cost pricing should reflect the coal price stability. Journal of China coal., 33, 15-17.

[18] Shang, Y. 2008. Resource tax reform - a new page of green tax. Journal of contemporary economy., 11, 124-125.

[19] Wang, M. 2010. China resource research review. Economic research Tribune, 33: 18-20.

[20] Zhang, Z., Guo, J. E., Qian, D., Xue, Y., \& Cai, L. 2013. Effects and mechanism of influence of China's resource tax reform: A regional perspective. Energy Economics, 36, 676-685. 
[21] Xu, X., Xu, X., Chen, Q., \& Che, Y. 2015. The impact on regional "resource curse" by coal resource tax reform in China-A dynamic CGE appraisal. Resources Policy, 45, 277-289.

[22] Deng, H. 2007. Comparative study environment tax system and its reference for China. Journal of tax and economy., 3, 95-100.

[23] Xu, X. 2012. Reform of resource taxes can adjust the regional difference, energy conservation and emissions reduction? dynamic analysis of the regional CGE model of multiple. Journal of economic science., 5, 45-54.

[24] Lin, B, Liu, X \& Zou, C. 2012. The resource tax reform in coal, for example of resource economics analysis. Chinese academy of social sciences, $2,58-78$.

[25] Lin, B, and He, X. 2008. Chinese Oil and Gas Depletion Costs and Macroeconomic Impacts of Resource Tax. Economic Research Journal., 5, 94-104.

[26] Zhong, M, Ceng, A, \& Huang, J. 2016. The impact of the reform of the metal resource tax from the perspective of the national resource security strategy. China population, resources and environment, 26 (6): 130-138.
[27] Bollen J. 2015. The value of air pollution co-benefits of climate policies: analysis with a global sector-trade CGE model called World Scan. Technological Forecasting and Social Change., 90, 178-191

[28] Doumax, V., Philip, J. M., \& Sarasa, C. 2014. Biofuels, tax policies and oil prices in France: Insights from a dynamic CGE model. Energy Policy, 66, 603-614.

[29] Gao, X., \& Zhao, E. 2014 China's oil and gas resources based on compensate for resource depletion rate optimization study. China population resources and environment., 24, 102-108.

[30] Yin, A., Yang, S, \& Fang, L. 2013. Based on analysis of CGE model to simulate mineral resource tax rate. Journal of accounting monthly., 22, 41-44.

[31] Huang, Y., Guo, Z., \& Zhang, T. 2005. Application of CGE model of quantitative analysis of China's implementation of the feasibility of the energy environment tax policies. Urban environment and urban ecology., 2, 18-20.

[32] Ye, Z. 2009. Determination of fuel tax rate - based on CGE analysis. Journal of statistical research, 5, 86-93. 